\title{
Genetic population structure of European sprat Sprattus sprattus: differentiation across a steep environmental gradient in a small pelagic fish
}

\author{
Morten T. Limborg ${ }^{1,2, *}$, Jes S. Pedersen ${ }^{1}$, Jakob Hemmer-Hansen ${ }^{2}$, \\ Jonna Tomkiewicz ${ }^{3}$, Dorte Bekkevold ${ }^{2}$ \\ ${ }^{1}$ University of Copenhagen, Department of Biology, Centre of Social Evolution, Universitetsparken 15, \\ 2100 Copenhagen Ø, Denmark \\ ${ }^{2}$ Technical University of Denmark, National Institute of Aquatic Resources, Section for Population Genetics, Vejlsøvej 39, \\ 8600 Silkeborg, Denmark \\ ${ }^{3}$ Technical University of Denmark, National Institute of Aquatic Resources, Section for Population and Ecosystem Dynamics, \\ Kavalergården 6, 2920 Charlottenlund, Denmark
}

\begin{abstract}
Factors such as oceanographic retention, isolation by distance and secondary contact zones have, among others, been suggested to explain the low, but statistically significant, neutral population structure observed in many marine fishes. European sprat Sprattus sprattus L. is not known to display philopatric spawning behaviour or to exhibit local retention of eggs and larvae. It thus constitutes a good model for studying population structure in a characteristic small pelagic fish with high dispersal potential and an opportunistic life history. We analysed 931 specimens of sprat from 9 spawning locations in and around the North Sea and Baltic Sea area and from a geographically distant population from the Adriatic Sea. Analyses of 9 microsatellite loci revealed a sharp genetic division separating samples from the northeastern Atlantic Ocean and the Baltic Sea (pairwise $\theta=0.019$ to 0.035), concurring with a steep salinity gradient. We found, at most, weak structure among samples within the northeastern Atlantic region and within the Baltic Sea (pairwise $\theta=0.001$ to 0.009). The Adriatic Sea population was highly differentiated from all northern samples (pairwise $\theta=0.071$ to 0.092). Overall, the observed population structure resembles that of most other marine fishes studied in the North and Baltic Sea areas. Nevertheless, spatially explicit differences are observed among species, probably reflecting specific life histories. Such fine-scale population structures should be taken into account when considering complex ecosystem functions, e.g. in multispecies stock management.
\end{abstract}

KEY WORDS: European sprat · Population structure · Environmental gradients · Interspecific comparison $\cdot$ Salinity $\cdot$ Marine fishes $\cdot$ Microsatellite DNA

\section{INTRODUCTION}

Over the last decades ample evidence of significant, albeit commonly low, levels of genetic population differentiation has been accumulated for marine fishes (e.g. Ruzzante et al. 1998, Pampoulie et al. 2004, Jørgensen et al. 2005, Hemmer-Hansen et al. 2007b). These studies have challenged the long-held view of predominantly limited population structure in marine fishes inhabiting large coherent environments with few physical barriers. Different explanations have been proposed to account for observed population structure in marine fishes. For example, physical forcing by current systems and local gyres may retain eggs and larvae in local nursery areas (Ruzzante et al. 1998), and historical events (e.g. geological processes) can lead to genetic divergence of populations by isolating contingents of populations in temporary refugia 
(Hewitt 2004, Knowles \& Richards 2005). Furthermore, adaptation to local environments can lead to establishment of gene-flow barriers across environmental transition zones through hybrid inferiority (Barton \& Hewitt 1985).

The North Sea-Baltic Sea transition zone represents a major environmental gradient, characterised by a dramatic change in salinity over a few hundred kilometres from oceanic conditions (30 to 35\% ) in the Skagerrak to an average salinity of 8 to $10 \%$ in the Western Baltic Sea. The colonisation by marine species in the Baltic Sea is believed to have been achieved as a result of specific adaptations to life in a marginal environment (e.g. Ojaveer \& Kalejs 2005). In the North Sea-Baltic Sea transition zone salinity levels are expected to exert a significant selective pressure on local populations although other environmental factors, such as temperature dynamics, are also expected to play a role. Indeed, it has been shown that Baltic (Atlantic) cod Gadus morhua L. tolerate lower salinities during egg fertilisation and the egg phase compared with populations from the Skagerrak (Nissling \& Westin 1997). Timing of spawning also seems to conform to spatial and temporal production peaks (Tomkiewicz et al. 1998, Ojaveer \& Kalejs 2005).

Molecular studies have identified genetically distinct North Sea and Baltic Sea fish populations in, for example, Atlantic herring Clupea harengus L. (Bekkevold et al. 2005), turbot Psetta maxima L. (Nielsen et al. 2004), Atlantic cod Gadus morhua L. (Nielsen et al. 2003) and European flounder Platichthys flesus L. (HemmerHansen et al. 2007b), as well as in many other organisms such as algae and invertebrates (see Johannesson \& Andre 2006 for a review). Overall, studies suggest restricted gene flow across the North Sea-Baltic Sea transition zone, but spatial patterns vary among species. Thus, interspecific comparisons may reveal the relative importance of specific environmental factors and/or biological traits for shaping patterns of population structure (Patarnello et al. 2007).

European sprat Sprattus sprattus L. is a pelagic schooling clupeid fish. Tolerating temperatures down to $\sim 5^{\circ} \mathrm{C}$ (Nissling 2004) and salinities down to $\sim 4 \%$ (Whitehead 1985), this species has successfully colonised a wide range of environments. Sprat is distributed in the Atlantic Ocean from the Norwegian west coast in the north to Morocco in south, including the Baltic Sea, and in the northern Mediterranean Sea and the Black Sea (Whitehead 1985). In the northeast Atlantic, spawning sprat concentrate in the deep basins of the Baltic Sea, in the Skagerrak/Kattegat area, the southeastern North Sea (German Bight) and from the English Channel to the north along the British west coast (Parmanne et al. 1994 and references therein, ICES 2007). Spawning, however, occurs throughout the species' distribution, and philopatric spawning migrations have not been described (Köster et al. 2003b). Further, local abundance and interannual movement among feeding areas can show substantial variation (Stepputtis 2006). In comparison, other species, such as cod and herring inhabiting the same areas exhibit spawning characteristics including homing and local retention of eggs that may induce stronger genetic isolation among components (Voipio 1981, Iles \& Sinclair 1982, Aro 1989). In sprat, the continuous distribution of spawning habitat coupled with opportunistic vagrant behaviour (De Silva 1973, Alheit 1988) suggest limited barriers to gene flow among areas and lead to expectations of weak population differentiation in comparison with, for example, herring and cod. Based on mtDNA data, sprat has been divided into 2 major phylogenetic clades geographically separated by the Strait of Sicily, and 1 clade showing signs of a more recent (since 13000 to 7600 yr BP) northwards expansion into the North and Baltic seas from an Atlantic refugia (Debes et al. 2008). Within the Baltic Sea, differences in meristic and morphometric characters, otolith structure and area specific stock dynamics have led several authors to suggest the occurrence of reproductively isolated populations (e.g. Aro 1989, Ojaveer 1989). However, these hypotheses have not been evaluated using genetic markers with sufficient resolution for identifying small-scale population structure (but see Kozlovski 1988).

In the present study, highly variable microsatellite markers were used to analyse European sprat samples from major spawning areas ranging from the central Baltic Sea to the Celtic Sea in the northeastern Atlantic Ocean. We ask the following questions: (1) Does sprat exhibit population structure at large (among seas) as well as regional (within sea) scales? (2) Are potential barriers to gene flow concurrent with salinity gradients in the area? (3) How does sprat population structure compare with that of other fishes in the North Sea-Baltic Sea transition zone? (4) Which biological and physical factors are likely to explain differences and similarities among species?

\section{MATERIALS AND METHODS}

Sample collection. A total of 969 sprat were collected during peak spawning time (March to May) in major spawning areas in and around the North Sea and the Baltic Sea (Table 1, Fig. 1). In total, 9 locations were sampled, of which 2 (German Bight and Bornholm Basin) included temporal replicates to test for temporal stability of genetic composition within locations. The stage of maturity was determined for all specimens, except for the Adriatic Sea sample. Prefer- 


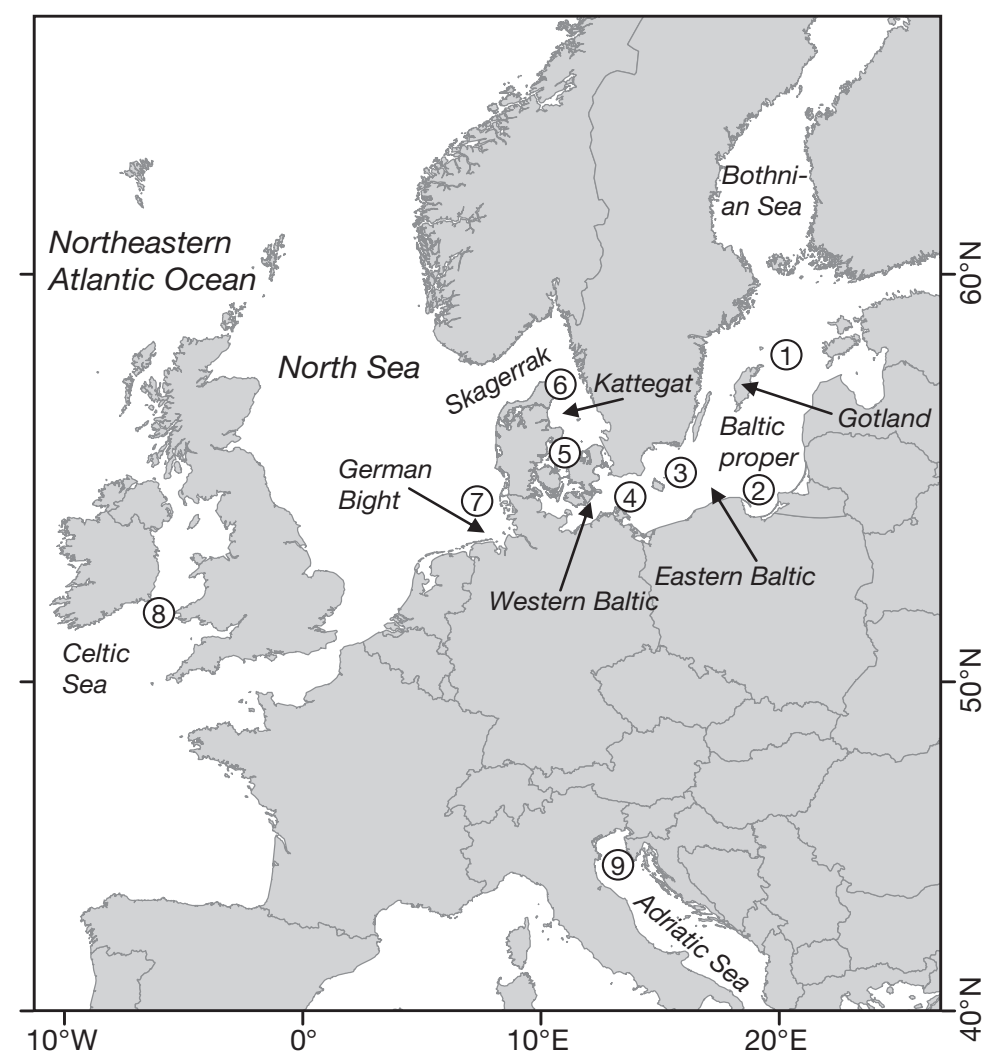

Fig. 1. Sprattus sprattus. Study area with sample locations. Circled numbers refer to the respective sample locations listed in Table 1

ably, only specimens in spawning condition were included in the genetic analyses to ensure proper representation of the local spawning populations. The Adriatic Sea specimens were caught in a local spawning area during spawning season. The Celtic Sea sample was collected outside the spawning season and could potentially include migrants from other populations.

Molecular analyses. DNA was extracted from fin or muscle tissue and stored in 96\% ethanol using the DNeasy kit 250 (QIAGEN). Genetic variation was analysed at 9 fluorescently labelled dinucleotide microsatellite loci developed for sprat: Spsp47D (TET), Spsp77C (HEX), Spsp133 (FAM), Spsp154 (TET), Spsp170 (FAM), Spsp202 (HEX), Spsp219 (HEX), Spsp256 (TET) and Spsp275 (FAM) (Dailianis et al. 2008). The loci were amplified separately by PCR using standard reagents. Annealing temperatures ranged from 56 to $62^{\circ} \mathrm{C}$ among loci (details in Dailianis et al. 2008). PCR amplified microsatellite fragments were analysed on a BaseStation 51 ${ }^{\mathrm{TM}}$ DNA fragment analyser (MJ Research) and gels were semi-automatically typed using the software CARTOGRAPHER 1.2.6 (MJ Geneworks). Depending on marker, between 10 and $50 \%$ of the individuals from each sample were reanalysed to ensure consistency of results. Further actions were taken to minimise genotyping errors, as suggested by Bonin et al. (2004). Thus, quality of PCR products was tested on a $6 \%$ agarose gel with a negative control to rule out contamination. Further, 4 controls of known genotypes were re-run on every gel to ensure consistent scoring of genotypes. Finally, all individuals in 3 samples were cross-typed by 2 persons independently, and a third sample was typed twice by the same person (typings separated by months). Fish with 4 or more missing single-locus genotypes were omitted from the dataset.

Table 1. Sprattus sprattus. Location and details of sprat samples collected. Also given are percentages of spawning fish per sample and mean allelic richness $\left(A_{\mathrm{r}}\right)$ corrected for the minimum sample size $(\mathrm{n}=56)$ of all loci per sample

\begin{tabular}{|c|c|c|c|c|c|c|c|}
\hline $\begin{array}{l}\text { Geographic } \\
\text { location }\end{array}$ & $\begin{array}{l}\text { Sample } \\
\text { ID }\end{array}$ & $\begin{array}{l}\text { Latitude, } \\
\text { longitude }\end{array}$ & Year & Month & $\begin{array}{l}\text { Proportion mature } \\
\text { and spawning }(\%)^{\mathrm{a}}\end{array}$ & $\begin{array}{l}\text { No. of } \\
\text { ind. }\end{array}$ & $A_{\mathrm{r}}$ \\
\hline (1) Gotland Deep & GOT & $58.24^{\circ} \mathrm{N}, 20.31^{\circ} \mathrm{E}$ & 2006 & May & 100 & 88 & 14.3 \\
\hline (2) Gdansk Deep & GDA & $54.43^{\circ} \mathrm{N}, 18.60^{\circ} \mathrm{E}$ & 2006 & Mar & 100 & 86 & 14.1 \\
\hline \multirow[t]{2}{*}{ (3) Bornholm Basin } & BOR05 & $55.13^{\circ} \mathrm{N}, 16.14^{\circ} \mathrm{E}$ & 2005 & Apr & 100 & 82 & 14.3 \\
\hline & BOR06 & $55.34^{\circ} \mathrm{N}, 16.25^{\circ} \mathrm{E}$ & 2006 & Mar & 100 & 88 & 13.8 \\
\hline (4) Arkona Basin & ARK & $55.08^{\circ} \mathrm{N}, 13.50^{\circ} \mathrm{E}$ & 2006 & May & 100 & 78 & 14.1 \\
\hline (5) Belt Sea & BEL & $55.42^{\circ} \mathrm{N}, 10.25^{\circ} \mathrm{E}$ & 2006 & Mar & 100 & 83 & 16.2 \\
\hline (6) Northern Kattegat & KAT & $57.42^{\circ} \mathrm{N}, 10.48^{\circ} \mathrm{E}$ & 2006 & Mar & 100 & 81 & 16.7 \\
\hline \multirow[t]{2}{*}{ (7) German Bight } & GER04 & $54.15^{\circ} \mathrm{N}, 07.12^{\circ} \mathrm{E}$ & 2004 & May & 100 & 88 & 18.5 \\
\hline & GER05 & $54.07^{\circ} \mathrm{N}, 07.47^{\circ} \mathrm{E}$ & 2005 & May & 100 & 87 & 18.1 \\
\hline (8) Celtic Sea & CEL & $51.59^{\circ} \mathrm{N}, 06.46^{\circ} \mathrm{W}$ & 2005 & Dec & $0^{\mathrm{b}}$ & 85 & 16.6 \\
\hline (9) Adriatic Sea & $\mathrm{ADR}$ & $45.36^{\circ} \mathrm{N}, 13.34^{\circ} \mathrm{E}$ & 2005 & Dec & $n a^{c}$ & 85 & 16.2 \\
\hline
\end{tabular}


Statistical analyses. The program MICRO-CHECKER 2.2.3 (Van Oosterhout et al. 2004) was used to test for technical artefacts, such as null alleles. Departure from Hardy-Weinberg equilibrium (HWE) was tested for each locus and sample using the method by Guo \& Thompson (1992) implemented in GENEPOP 3.4 (Raymond \& Rousset 1995). Analyses for departure from gametic phase equilibrium (linkage disequilibrium) between pairs of loci by means of exact tests were also performed using GENEPOP 3.4.

Observed and expected heterozygosities $\left(H_{\mathrm{O}}\right.$ and $H_{\mathrm{E}}$ ), Weir \& Cockerham's (1984) inbreeding coefficient $\left(F_{\mathrm{IS}}\right)$, numbers of alleles $(A)$ and allelic richness corrected for sample size $\left(A_{\mathrm{r}}\right)$ were calculated for each locus and sample using FSTAT 2.9.3 (Goudet 1995). Differences in allelic richness between the Baltic Sea samples: Gotland, Gdansk, Bornholm and Arkona (GOT, GDA, BOR and ARK, respectively), and samples from the northern Kattegat, German Bight and Celtic Sea (KAT, GER and CEL, respectively, hereafter, slightly inaccurately, referred to as the North Sea group) were tested in FSTAT 2.9.3 using permutation tests. FSTAT 2.9.3 was also used to estimate differentiation $\left(F_{\mathrm{ST}}\right)$ between each pair of samples and overall using Weir \& Cockerham's (1984) unbiased estimator $\theta$. Pairwise population differentiation was tested using contingency tests implemented in FSTAT 2.9.3. We used PCAGEN 1.3.1 (available at: www2.unil.ch/popgen/softwares/pcagen. $\mathrm{htm}$ ) to perform a principal component analysis (PCA) based on allele frequencies of all 11 samples and significance of each principal component (PC) was tested by 10000 randomisations. The proportions of genetic variation distributed between the Baltic Sea and North Sea groups as well as between temporal samples within locations (GER and BOR) were estimated using a hierarchical analysis of molecular variance (AMOVA) implemented in ARLEQUIN 3.11 (Schneider et al. 2000).

Salinity levels on spawning locations exhibit strong relationships with genetic structure in the Atlantic herring from the same area and are the environmental factors with the strongest explanatory power when analysing relationships between different environmental variables and population structure (Bekkevold et al. 2005). To test for such a relationship in sprat partial Mantel tests were applied on all northern samples (i.e. omitting the Adriatic Sea, ADR) to test the correlation between $\theta$ values and either geographic distance (shortest waterway distance) or 'environmental distance' (applying difference in mean surface salinity as a proxy) alone, and controlling for each of the explanatory factors. These analyses were performed in FSTAT 2.9.3 using 10000 randomisations.

\section{RESULTS}

\section{Genetic variation}

Overall, scoring of genotypes was consistent between persons, months and reanalyses. However, 38 spurious genotypes (usually inconsistent scoring of genotypes and/or consistently weak amplification of fragments) were omitted from further analyses leaving 931 individuals (78 to 88 per population) of which $94.9 \%$ of all genotypes were scored successfully (Appendix 1). The MICRO-CHECKER analyses did not suggest any major scoring problems, albeit 28 of 99 tests ( $28.3 \%$ ) suggested minor problems with null alleles. Null allele frequencies (r) estimated according to Chakraborty et al. (1992) were in the range of $r=0.04$ to 0.17 (average $=0.08$ ) and distributed among 8 of 9 loci and all samples. Considering this wide and non-systematic distribution of potential null alleles and the fact that $\theta$ values did not appear to be seriously biased by the occurrence of null alleles (see below), genotype frequencies were not corrected before estimating population differentiation. Of 99 tests, 8 tests, distributed over 4 different loci (Spsp77C, Spsp133, Spsp154 and Spsp 170), and 7 samples showed deviations from HWE ( $\alpha=0.05$; Appendix 1 ) after adjusting for multiple sequential tests (Rice 1989). No significant gametic phase disequilibrium was found across loci and samples after adjusting for multiple sequential tests. $A_{\mathrm{r}}$ varied across loci (Appendix 1). Averaged over-loci estimates of $A_{\mathrm{r}}$ did not vary significantly among samples within the 2 major groups (see Table 1). However, comparing groups of samples within each area (omitting BEL representing the central North Sea-Baltic Sea transition zone) revealed significantly lower genetic diversity in the Baltic Sea samples $\left(A_{\mathrm{r}}=14.05 \pm 0.19\right.$ [mean $\pm \mathrm{SD}$ ] $)$ compared with the North Sea group samples $\left(A_{\mathrm{r}}=17.10 \pm 0.84, \mathrm{p}<0.01\right)$.

\section{Temporal genetic differentiation}

No differentiation was found between temporal (2004 and 2005) comparisons from the German Bight $(\theta=$ $0.002 ; 95 \%$ confidence interval $[\mathrm{CI}]=-0.001$ to 0.005 , p > 0.05), while samples from the Bornholm Basin (2005 and 2006) exhibited statistically significant, although low, differentiation $(\theta=0.006 ; 95 \% \mathrm{CI}=0.002$ to $0.010, \mathrm{p}<0.05)$. However, differentiation was statistically non-significant when one or more of the loci exhibiting deviations from HWE were removed (not shown).

\section{Spatial analyses of population differentiation}

Due to the minor, but significant, temporal differentiation in the Bornholm Basin and the fact that sample 
sizes were large and fairly equal among collections, only the most recent temporal replicates (BOR06 and GER05) were used for spatial comparisons to reduce the overall temporal separation in spatial comparisons. Pairwise $\theta$ values for all 9 locations are shown in Table 2 and ranged from 0.001 to 0.089 with an overall $\theta$ of 0.030 (95\% CI $=0.015$ to 0.048 , $\mathrm{p}<0.001)$. The Adriatic Sea population was highly differentiated from all northern samples (pairwise $\theta=0.073$ to $0.089, p<0.001$ for all comparisons).

Pairwise comparisons between samples within the North Sea group and the Baltic Sea group, respectively, revealed low $\theta$ values (between 0.001 and 0.009). Nonetheless, all 3 pairwise tests within the North Sea group and 3 of 6 tests within the Baltic Sea group were statistically significant even after correcting for multiple tests (Table 2). Pairwise comparisons between North Sea and Baltic Sea samples ranged from 0.019 to 0.031 , and all were highly significant $(p<0.001)$. The Belt Sea sample was significantly differentiated from all neighbouring samples $(p<0.001)$ and showed a general pattern of intermediate levels of differentiation compared with North Sea-Baltic Sea comparisons $(\theta=0.012$ to 0.022). This pattern of a strong genetic differentiation between the Baltic Sea and the North Sea mirrored the steep gradient in average surface salinity (Fig. 2).

A potential bias in population differentiation estimates due to 4 loci not exhibiting HWE in several samples (see above) was tested further by recalculating overall, as well as pairwise, $\theta$ after omitting each of these loci in turn and when omitting all 4 loci simultaneously. None of these estimates returned greatly differing overall values of $\theta$ and estimates obtained by omitting either Spsp77C, Spsp133 or Spsp154, respectively, resulted in slightly higher overall $\theta$ values $(\theta=0.032$ to 0.033$)$. Thus, including information from those 3 loci is not expected to inflate estimates of differentiations across regions. Similarly, pairwise $\theta$ estimates changed little in any of the reanalyses testing the effect of all 4 loci (see above), although comparisons involving samples from the North Sea group gained statistical significance in a few cases. These minor changes do not warrant the exclusion of any of the 4 loci in the present study but illustrate that great caution should be taken when interpreting low $(<0.01)$ but statistically significant $F_{\mathrm{ST}}$ estimates due to high

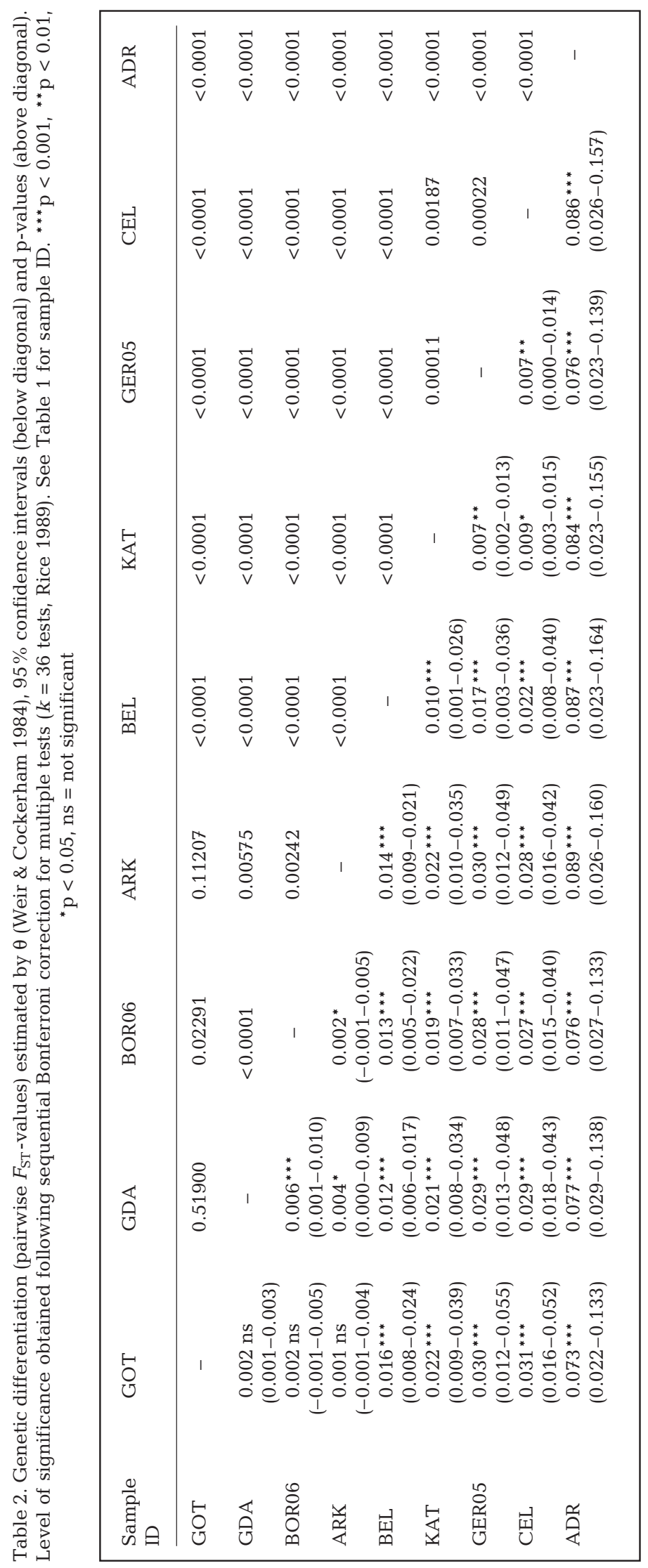


interlocus variability (Chapuis \& Estoup 2007, Nielsen et al. 2009), especially in high gene flow scenarios.

Only the first 2 principal components of the PCA explained a significant proportion of the total genetic variance (PC1 and 2, p $<0.001$; PC3 to 10, p = 1.000). The first principal component (PC1, explaining $42 \%$ of the variance) in the PCA plot (Fig. 3) mainly separated the ADR population from all others, while PC2 (explaining $32 \%$ of the variance) separated samples from the North Sea group and Baltic Sea group into 2 major clusters with the Belt Sea sample located in between (Fig. 3). The Baltic Sea cluster did not reveal any obvious spatial pattern while a weak spatial pattern was evident within the North Sea group. The 2 temporal samples from the German Bight clustered together and exhibited statistically significant differentiation from the other samples in the North Sea area

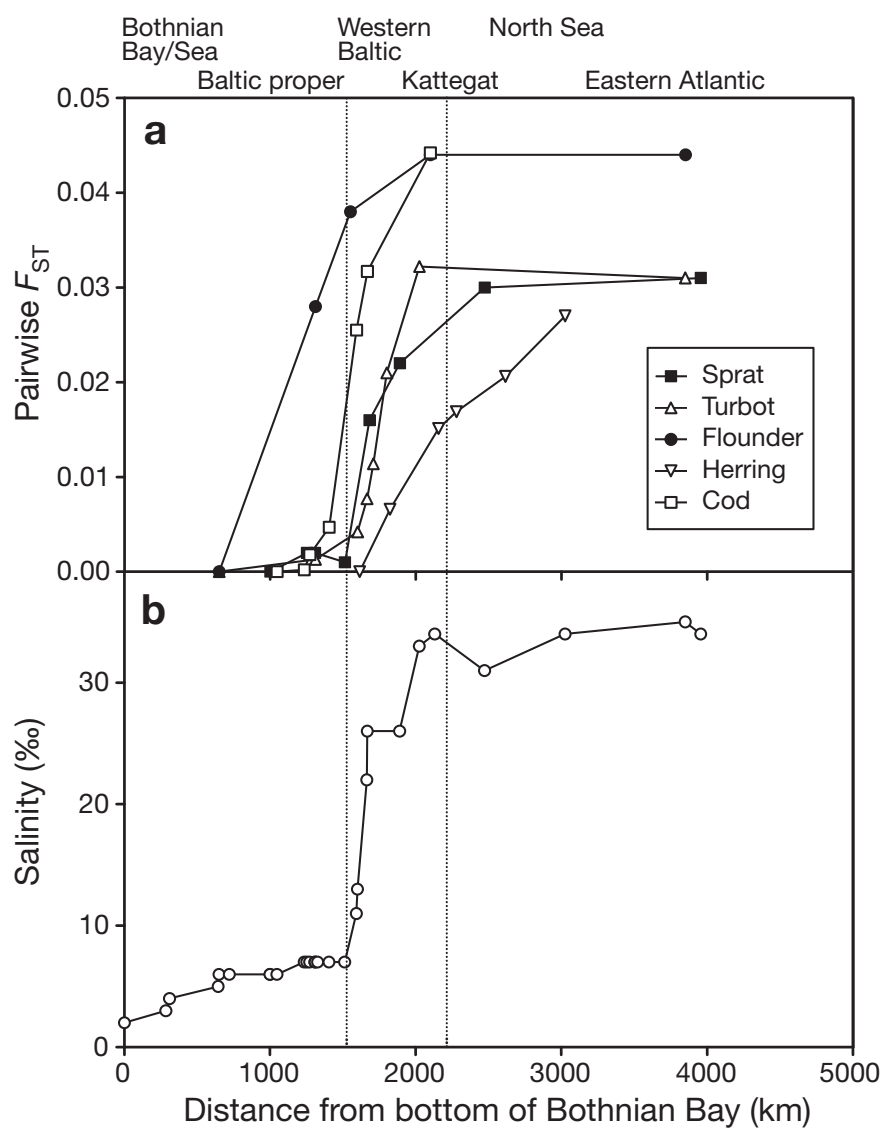

Fig. 2. Sprattus sprattus, Platichthys flesus, Gadus morhua, Psetta maxima and Clupea harengus. (a) Genetic differentiation (pairwise $F_{\mathrm{ST}}$ ) between the most northern Baltic sample and samples following a geographical transect from the northern Baltic Sea to the Atlantic Ocean for flounder (Hemmer-Hansen et al. 2007b), cod (Nielsen et al. 2003), turbot (Nielsen et al. 2004), sprat (present study) and herring (Bekkevold et al. 2005). (b) Average surface salinity from the Bothnian Bay to the northeastern Atlantic Ocean. Vertical lines indicate the area of the transition zone where the salinity gradient is steepest
(KAT and CEL; Fig. 3, Table 2). Another PCA omitting the ADR population revealed no further spatial pattern among the remaining samples (not shown). The hierarchical AMOVA grouping temporal samples from the German Bight and Bornholm Basin, respectively, revealed a much higher degree of spatial $(2.85 \%, \mathrm{p}>$ $0.05)$ than temporal $(0.15 \%, \mathrm{p}<0.05)$ genetic variance, although only the temporal comparison was significant. The lack of statistical significance for the former estimate was probably an effect of reduced statistical power in the spatial comparison due to fewer degrees of freedom compared with the temporal comparison (df $=1$ and 2, respectively). Another AMOVA (omitting BEL) showed that a significant proportion of the observed genetic variation could be explained by differentiation between the North Sea group and Baltic Sea group $(2.21 \%, p<0.05)$ while differentiation among locations within these groups explained a much lower part of the overall genetic variation $(0.32 \%, p<$ 0.001). Again, the lower level of statistical significance for the between-group comparison is probably explained by lower statistical power compared with the within-group comparison ( $\mathrm{df}=1$ and 5, respectively). The partial Mantel tests revealed a higher correlation between genetic and environmental (salinity) distance $(\mathrm{r}=0.98, \mathrm{p}=0.0001)$ than between genetic and geographic distance $(\mathrm{r}=0.63, \mathrm{p}=0.0003)$. When controlling for environmental distance, the geographic distance parameter became non-significant $(\mathrm{r}=0.63, \mathrm{p}=$ 0.71) while the environmental parameter remained highly significant $(\mathrm{r}=0.76, \mathrm{p}=0.0001$ ) when controlling for geographic distance.

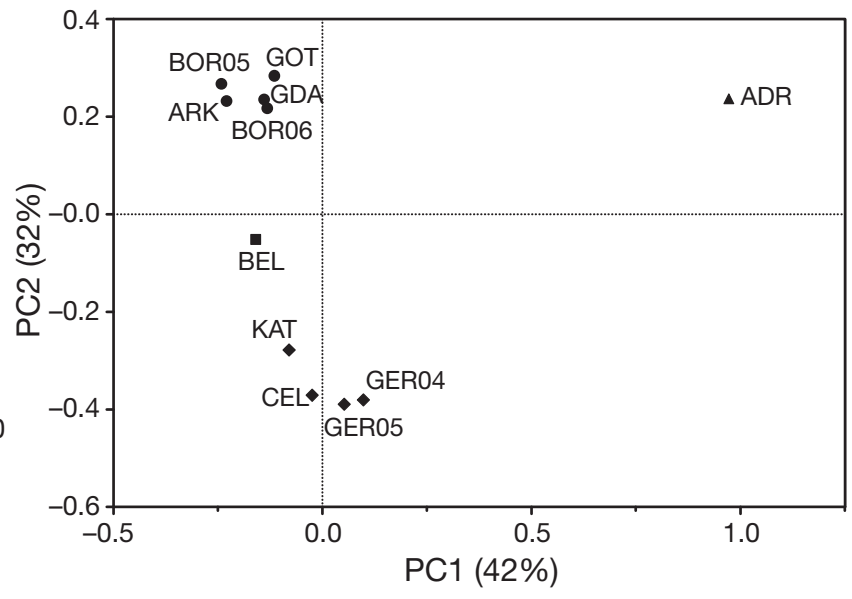

Fig. 3. Sprattus sprattus. Plot of first 2 principal components of genetic variation in sprat samples from (•) the Baltic Sea,

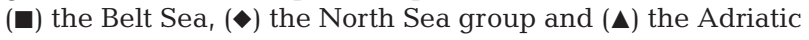
Sea. See Table 1 for sample locations. Principal components (PC) 3 to 10 each explained $<6.62 \%$ of the total variation. p-values for the proportion of inertia of each axis: PC1 $=0.01$, $\mathrm{PC} 2=0.01$ and $\mathrm{PC} 3$ to $\mathrm{PC} 10=1.00$ 


\section{DISCUSSION}

\section{Large-scale population structure}

This is the first study to demonstrate highly significant population structure in European sprat based on highly polymorphic molecular markers. We estimated an overall $F_{\mathrm{ST}}$ of 0.030 (95\% CI $=0.015$ to 0.048$)$, which corresponds with similar scale studies of other marine fishes (Ruzzante et al. 1998, Nielsen et al. 2003, 2004, Bekkevold et al. 2005, Hemmer-Hansen et al. 2007b). We found a sharp genetic division between North Sea and Baltic Sea populations (see below). The Adriatic Sea population exhibited a relatively large divergence from all other samples (Table 2, Fig. 3). This is in concordance with mtDNA data showing evidence for 2 'major clades', with one distributed in the eastern Mediterranean Sea, including the Adriatic Sea and Black Sea, and another in the western Mediterranean Sea, northeast Atlantic Ocean, North Sea and Baltic Sea (Debes et al. 2008). Contrary to the present study, Debes et al. (2008) found no differentiation in allele frequencies among samples ranging from the Bay of Biscay to the Western Baltic. Rather, when grouping samples from the northeast Atlantic, North Sea and Baltic Sea, Debes et al. (2008) found a unimodal mismatch distribution and a 'star-burst'-shaped haplotype network supporting a 'recent' (i.e. following postglacial creation of marine habitats 13000 to 7600 yr BP) northward range expansion (Debes et al. 2008). These combined results suggest a recent (within the last $10000 \mathrm{yr}$ ) split between northeast Atlantic and Baltic Sea populations. This would translate into approximately 4000 to 5000 sprat generations, which is assumed to be sufficient time for generating the observed levels of genetic differentiation through genetic drift, when considering realistic combinations of effective population size $\left(N_{\mathrm{e}}\right)$ and migration rate $(m)$ for marine fishes (Hauser \& Carvalho 2008).

\section{Population structure within the North Sea and the Baltic Sea}

When studying spatial population structure in high gene flow scenarios, as in most marine fishes, it is vital to define a genetically unique population (Waples \& Gaggiotti 2006). Here we apply the weakest criterion from Waples \& Gaggiotti (2006) for defining populations from an evolutionary (and not demographic) paradigm, $N_{\mathrm{e}} m<25$. Choosing a fixed threshold value will always be prone to subjectivity. However, the above threshold conforms to $F_{\mathrm{ST}}$ values as low as $\sim 0.01$ being statistically highly significant (Waples \& Gaggiotti 2006), which is often the case for marine fishes. Thus, despite a few statistically significant pairwise comparisons within the Baltic Sea (Table 2), our data most probably reflect an overall pattern of no spatial structure as inferred from, assumingly, neutral microsatellite markers. No study has revealed evidence of a temporally stable genetic structure of sprat within the Baltic Sea, and a previous approach applying allozyme markers also failed to distinguish among spawning components (Kozlovski 1988).

Within the North Sea/North Atlantic group a weak structure, at most, was detected among populations (Fig. 3, Table 2). These low estimates of spatial differentiation mirror results obtained for other fishes in the area, e.g. herring (Mariani et al. 2005) and flounder (Hemmer-Hansen et al. 2007b). The Celtic Sea sample did, however, not include spawning individuals and our estimate of differentiation might, thus, be an underestimate due to the potential inclusion of transient migrants from other populations. Nonetheless, no study has indicated that such migrations occur. Based on allozyme markers and phenotypic traits, Næevdal (1968) suggested the occurrence of reproductively isolated components of sprat among Norwegian fjords, as also reported in herring (Bekkevold et al. 2005) and cod (Knutsen et al. 2007). However, more detailed sampling is needed for a comprehensive analysis of population structure within the North Sea. The present results should not be interpreted as evidence that sprat in the North Sea and Baltic Sea areas, respectively, are effectively panmictic. For instance, adaptive genetic divergence at genes exposed to local selection can easily be overlooked when studying presumably neutral (i.e. non-functional) variation in a high gene flow scenario (e.g. see Hemmer-Hansen et al. 2007a).

\section{The North Sea-Baltic Sea transition zone}

Our results support the existence of a barrier to gene flow separating the northern Kattegat, North Sea and Celtic Sea from Baltic Sea samples (Figs. 2 \& 4), with the Belt Sea sample representing a genetically intermediate transition zone. The clustering into 2 regions was further supported by the AMOVA results, which revealed that a higher degree of overall variation was explained by spatial variation between the 2 clusters compared with variation within clusters and between years. If we consider a scenario where 'genetically pure' populations occur in the Baltic Sea and the North Sea area, the narrow transition zone could reflect either a contact zone constituted of genetically admixed individuals (hybrids), or a zone where individuals from the 2 populations mix mechanically (i.e. a Wahlund effect). In theory, the latter scenario will lead to deviations from HWE causing higher than expected inbreed- 


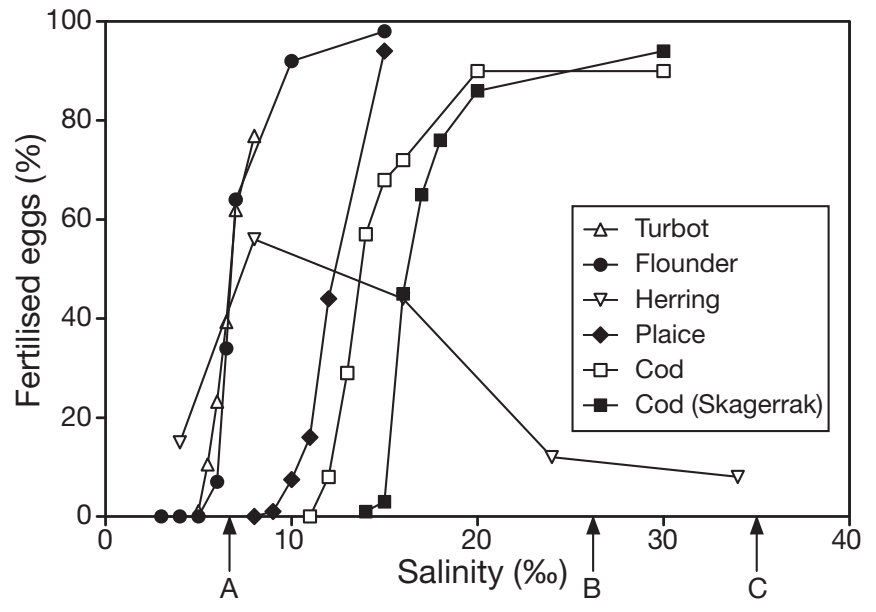

Fig. 4. Psetta maxima, Gadus morhua, Platichthys flesus, Pleuronectes platessa and Clupea harengus. Fertilisation success as a function of salinity for turbot (Nissling et al. 2006), cod (Nissling \& Westin 1997), flounder (with pelagic eggs), plaice Pleuronectes platessa (Nissling et al. 2002) and herring (Griffin et al. 1998). All individuals originated from Baltic Sea populations unless otherwise stated. Arrows A, B and C show approximate surface salinities in the Baltic Sea proper, Kattegat and North Sea, respectively

ing coefficients $\left(F_{\mathrm{IS}}\right)$, but the multi-locus $F_{\mathrm{IS}}$ estimate for the BEL sample is not fundamentally different from other samples (Appendix 1). The genetic composition of the BEL sample was further evaluated by simulating a mechanically mixed (50:50) sample of sprat from the 'pure' North Sea and Baltic Sea populations (using the procedure described in Nielsen et al. 2001). This simulated sample did not deviate significantly from HWE at any of the 9 microsatellite loci (results not shown), demonstrating that genetic resolution is too low for statistical detection of a potential Wahlund effect caused by mechanical mixing. Furthermore, calculating individual admixture proportions in the BEL sample, again assuming Baltic and North sea sprat as 'pure' contributing populations (following the procedure described in Nielsen et al. 2003) revealed that the distribution of BEL genotypes resembled a scenario of genetically admixed individuals, rather than mechanical mixing (results not shown).

The partial Mantel tests revealed a stronger correlation between genetic distance and difference in salinity on spawning sites, than between genetic and geographic distance. Results thus clearly demonstrate that isolation by distance is unlikely to account for the observed population structure per se (Figs. $2 \& 3$ ). Although we cannot infer causal evolutionary processes directly from simple correlation analyses, our results suggest that salinity differences (and/or some correlated factor) play a role in maintaining reproductive barriers between the North Sea and Baltic Sea.
Other factors also probably reinforce reproductive isolation by limiting temporal and/or spatial overlaps of different groups of spawners and juveniles. Such potential factors include physical forcing (Hinrichsen et al. 2005) and environmentally induced spawning behaviour and/or survival (Köster et al. 2003a). However, these possible effects need not be mutually exclusive with an environmentally (e.g. salinity) induced barrier to gene flow.

Reduced allelic richness was observed in Baltic Sea sprat compared with samples from the northern Kattegat, North Sea and Celtic Sea (Table 1). Similar results have been reported for cod (Nielsen et al. 2003), herring (Bekkevold et al. 2005) and flounder (HemmerHansen et al. 2007b). Founding of new populations is commonly associated with loss of genetic variation (Nei et al. 1975). The shallow phylogeography of northeast Atlantic sprat populations (Debes et al. 2008) and the geographically marginal population in the Baltic Sea suggest a recent colonisation by sprat, potentially associated with reinforcement of adaptive divergence in response to low and varying salinity in the Baltic Sea (i.e. a primary contact zone scenario, Garant et al. 2007). However, alternative scenarios, such as a secondary contact zone created during the last glacial retreat (Hewitt 2004, Knowles \& Richards 2005), as often suggested for invertebrates in this region (e.g. Väinölä 2003), cannot be ruled out based on the present data.

\section{Interspecific comparison of genetic structure}

Our study contributes to existing knowledge of marked genetic clines in marine fishes in the Baltic Sea and adjacent northeastern Atlantic regions. The threshold values in salinity for successful spawning (Fig. 4) further indicate that Baltic Sea components of most marine fishes indeed represent marginal populations with distributional boundaries governed by one or more environmental factors. Cod, in particular, is restricted to the deeper more saline water for successful spawning in the Baltic Sea basins (Fig. 4). Interspecific differences in population structure patterns may reflect variation in, for example, spawning strategy, salinity tolerance (Fig. 4) and/or other traits. In this respect, it is intriguing that the geographic location of the most pronounced barriers to gene flow between Baltic Sea and North Sea populations indeed seems to differ among species (Fig. 2). Bekkevold et al. (2005) showed that on a macro-geographical scale herring exhibits highly significant population structure with differentiation occurring across multiple barriers within the transition zone. This is similar to the 1-dimensional patterns observed for turbot (Nielsen et al. 2004) and 
sprat (present study). In these species, genetic divisions mirror surface salinity gradients (Fig. 2). In contrast, areas of most restricted gene flow do not directly correlate with the surface salinity gradient for cod and flounder (Fig. 2). For cod populations, a major division between components of the Western Baltic and the Baltic Sea proper occurs around the Bornholm Basin (Fig. 2, Nielsen et al. 2003). Indeed, the salinity and dissolved oxygen conditions of the Bornholm Basin presently make it the only major area suitable for cod spawning in the Baltic Sea (MacKenzie et al. 2000, Köster et al. 2005). In flounder, neutral genetic differentiation is comparatively low among populations from the Skagerrak and southwestern Baltic, and instead a sharp division is observed near Gotland in the central Baltic Sea (Fig. 2, Hemmer-Hansen et al. 2007b). This division has been ascribed to the occurrence of a shift in life history strategy with populations north of this division having demersal eggs as opposed to pelagic eggs (Nissling et al. 2002). When considering these interspecific differences, one cannot rule out small-scale sampling effects due to different sampling locations among species. However, even with a cautious interpretation we see strong evidence for interesting differences in the pattern of genetic structure, inferred from neutral microsatellites, among the species compared in Fig. 2. This suggests that multi-species approaches in future studies might be rewarding in terms of untangling key evolutionary mechanisms shaping population structure in the sea and e.g. for implementing multispecies stock management. Furthermore, recent studies have provided more direct evidence for the existence of adaptive evolution in the marine environment, despite a background of high gene flow (Hemmer-Hansen et al. 2007a, Larsen et al. 2007, 2008). Inferring the relative importance of external evolutionary drivers and species-specific traits like population history, life history strategy, and migratory and reproductive behaviours remains a great challenge. Therefore, it must be stressed that it is difficult to assess the relative importance of salinity compared with other such factors. Nevertheless, salinity seems to be a key external factor potentially driving evolution and shaping dispersal and population distribution patterns of marine organisms inhabiting the Baltic Sea, including European sprat.

Acknowledgements. The authors are grateful to G. Kraus, R. Hanel, J. P. Hermann, W. Grygiel, G. Kornilovs, H. Haslob, K. Jensen and J. Ellis for help with sample collection, and to N. D. Jong, K. L. D. Mensberg, D. Meldrup and T. B. Christensen for excellent assistance in the laboratory. E. E. Nielsen and 4 anonymous referees are thanked for constructive comments on earlier drafts of this paper. This work is part of the research project UNCOVER (www.uncover.eu, FP6-2004-18 SSP-4, Proposal no. 22717) funded by the European Union within the 6th framework programme. R. Hanel, C. Tsigenopoulos and C. Andre contributed invaluable help and discussion via the European Network of Excellence MARBEF NoE (CT-2003505446).

\section{LITERATURE CITED}

Alheit J (1988) Reproductive biology of sprat (Sprattus sprattus): factors determining annual egg production. J Cons Int Explor Mer 44:162-168

Aro E (1989) A review of fish migration in the Baltic. Rapp P-V Réun Cons Int Explor Mer 190:72-96

> Barton NH, Hewitt GM (1985) Analysis of hybrid zones. Annu Rev Ecol Syst 16:113-148

> Bekkevold D, Andre C, Dahlgren TG, Clausen LAW and others (2005) Environmental correlates of population differentiation in Atlantic herring. Evolution 59:2656-2668

Bonin A, Bellemain E, Eidesen PB, Pompanon F, Brochmann C, Taberlet P (2004) How to track and assess genotyping errors in population genetics studies. Mol Ecol 13: 3261-3273

> Chakraborty R, Deandrade M, Daiger SP, Budowle B (1992) Apparent heterozygote deficiencies observed in DNA typing data and their implications in forensic applications. Ann Hum Genet 56:45-57

> Chapuis MP, Estoup A (2007) Microsatellite null alleles and estimation of population differentiation. Mol Biol Evol 24: 621-631

Dailianis T, Limborg M, Hanel R, Bekkevold D, Lagnel J, Magoulas A, Tsigenopoulos CS (2008) Characterization of nine polymorphic microsatellite markers in sprat (Sprattus sprattus L.). Mol Ecol Resour 8:861-863

> Debes PV, Zachos FE, Hanel R (2008) Mitochondrial phylogeography of the European sprat (Sprattus sprattus L., Clupeidae) reveals isolated climatically vulnerable populations in the Mediterranean Sea and range expansion in the northeast Atlantic. Mol Ecol 17:3873-3888

> De Silva SS (1973) Aspects of reproductive biology of sprat, Sprattus sprattus (L.) in inshore waters of west coast of Scotland. J Fish Biol 5:689-705

Garant D, Forde SE, Hendry AP (2007) The multifarious effects of dispersal and gene flow on contemporary adaptation. Funct Ecol 21:434-443

Goudet J (1995) FSTAT (version 1.2): a computer program to calculate F-statistics. J Hered 86:485-486

Griffin FJ, Pillai MC, Vines CA, Kaaria J, Hibbard-Robbins T, Yanagimachi R, Cherr GN (1998) Effects of salinity on sperm motility, fertilization, and development in the Pacific herring, Clupea pallasi. Biol Bull (Woods Hole) 194:25-35

Guo SW, Thompson EA (1992) Performing the exact test of Hardy-Weinberg proportion for multiple alleles. Biometrics 48:361-372

Hauser L, Carvalho GR (2008) Paradigm shifts in marine fisheries genetics: ugly hypotheses slain by beautiful facts. Fish Fish 9:333-362

Hemmer-Hansen J, Nielsen EE, Frydenberg J, Loeschcke V (2007a) Adaptive divergence in a high gene flow environment: Hsc70 variation in the European flounder (Platichthys flesus L.). Heredity 99:592-600

> Hemmer-Hansen J, Nielsen EE, Grønkjær P, Loeschcke V (2007b) Evolutionary mechanisms shaping the genetic population structure of marine fishes; lessons from the European flounder (Platichthys flesus L.). Mol Ecol 16: 3104-3118

Hewitt GM (2004) Genetic consequences of climatic oscilla- 
tions in the Quaternary. Philos Trans R Soc Lond B Biol Sci 359:183-195

Hinrichsen HH, Kraus G, Voss R, Stepputtis D, Baumann H (2005) The general distribution pattern and mixing probability of Baltic sprat juvenile populations. J Mar Syst 58: $52-66$

ICES (2007) Report of the herring assessment working group for the area south of $62^{\circ} \mathrm{N}$ (HAWG). International Council for the Exploration of the Sea, Copenhagen

Iles TD, Sinclair M (1982) Atlantic herring: stock discreteness and abundance. Science 215:627-633

Johannesson K, Andre C (2006) Life on the margin: genetic isolation and diversity loss in a peripheral marine ecosystem, the Baltic Sea. Mol Ecol 15:2013-2029

Jørgensen HBH, Hansen MM, Bekkevold D, Ruzzante DE, Loeschcke V (2005) Marine landscapes and population genetic structure of herring (Clupea harengus L.) in the Baltic Sea. Mol Ecol 14:3219-3234

Knowles LL, Richards CL (2005) Importance of genetic drift during Pleistocene divergence as revealed by analyses of genomic variation. Mol Ecol 14:4023-4032

Knutsen H, Olsen EM, Ciannelli L, Espeland SH and others (2007) Egg distribution, bottom topography and smallscale cod population structure in a coastal marine system. Mar Ecol Prog Ser 333:249-255

Köster FW, Hinrichsen HH, Schnack D, St John MA and others (2003a) Recruitment of Baltic cod and sprat stocks: identification of critical life stages and incorporation of environmental variability into stock-recruitment relationships. Sci Mar 67:129-154

Köster FW, Möllmann C, Neuenfeldt S, Vinther M and others (2003b) Fish stock development in the Central Baltic Sea (1974-1999) in relation to variability in the environment. ICES Mar Sci Symp 219:294-306

Köster F, Möllmann C, Hinrichsen HH, Wieland K and others (2005) Baltic cod recruitment - the impact of climate variability on key processes. ICES J Mar Sci 62:1408-1425

Kozlovski AY (1988) Preliminary results of the studies of the Baltic sprat stock structure using genetic-biochemical methods. Fisch-Forsch 26:74-76 (in Russian)

Larsen PF, Nielsen EE, Williams TD, Hemmer-Hansen J and others (2007) Adaptive differences in gene expression in European flounder (Platichthys flesus). Mol Ecol 16: 4674-4683

> Larsen PF, Nielsen EE, Williams TD, Loeschcke V (2008) Intraspecific variation in expression of candidate genes for osmoregulation, heme biosynthesis and stress resistance suggests local adaptation in European flounder (Platichthys flesus). Heredity 101:247-259

>acKenzie BR, Hinrichsen HH, Plikshs M, Wieland K, Zezera AS (2000) Quantifying environmental heterogeneity: habitat size necessary for successful development of cod Gadus morhua eggs in the Baltic Sea. Mar Ecol Prog Ser 193:143-156

- Mariani S, Hutchinson WF, Hatfield EMC, Ruzzante DE and others (2005) North Sea herring population structure revealed by microsatellite analysis. Mar Ecol Prog Ser 303: 245-257

Nævdal G (1968) Studies on hemoglobins and serum proteins in sprat from Norwegian waters. Fiskeridir Skr Ser Havunders 14:160-182

Nei M, Maruyama T, Chakraborty R (1975) Bottleneck effect and genetic variability in populations. Evolution 29:1-10

Nielsen EE, Hansen MM, Bach LA (2001) Looking for a needle in a haystack: discovery of indigenous Atlantic salmon (Salmo salar L.) in stocked populations. Conserv Gen 2: 219-232
Nielsen EE, Hansen MM, Ruzzante DE, Meldrup D, Grønkjær P (2003) Evidence of a hybrid-zone in Atlantic cod (Gadus morhua) in the Baltic and the Danish Belt Sea revealed by individual admixture analysis. Mol Ecol 12:1497-1508

> Nielsen EE, Nielsen PH, Meldrup D, Hansen MM (2004) Genetic population structure of turbot (Scophthalmus maximus L.) supports the presence of multiple hybrid zones for marine fishes in the transition zone between the Baltic Sea and the North Sea. Mol Ecol 13:585-595

Nielsen EE, Wright PJ, Hemmer-Hansen J, Poulsen AN, Gibb IM, Meldrup D (2009) Microgeographical population structure of cod Gadus morhua in the North Sea and west of Scotland: the role of sampling loci and individuals. Mar Ecol Prog Ser 376:213-225

Nissling A (2004) Effects of temperature on egg and larval survival of cod (Gadus morhua) and sprat (Sprattus sprattus) in the Baltic Sea - implications for stock development. Hydrobiologia 514:115-123

Nissling A, Westin L (1997) Salinity requirements for successful spawning of Baltic and Belt Sea cod and the potential for cod stock interactions in the Baltic Sea. Mar Ecol Prog Ser 152:261-271

> Nissling A, Westin L, Hjerne O (2002) Reproductive success in relation to salinity for three flatfish species, dab (Limanda limanda), plaice (Pleuronectes platessa), and flounder (Pleuronectes flesus), in the brackish water Baltic Sea. ICES J Mar Sci 59:93-108

Nissling A, Johansson U, Jacobsson M (2006) Effects of salinity and temperature conditions on the reproductive success of turbot (Scophthalmus maximus) in the Baltic Sea. Fish Res 80:230-238

Ojaveer E (1989) Population structure of pelagic fishes in the Baltic. Rapp P-V Réun Cons Int Explor Mer 190:17-21

> Ojaveer E, Kalejs M (2005) The impact of climate change on the adaptation of marine fish in the Baltic Sea. ICES J Mar Sci 62:1492-1500

> Pampoulie C, Gysels ES, Maes GE, Hellemans B, Leentjes V, Jones AG, Volckaert FAM (2004) Evidence for fine-scale genetic structure and estuarine colonisation in a potential high gene flow marine goby (Pomatoschistus minutus). Heredity 92:434-445

Parmanne R, Rechlin O, Sjöstrand B (1994) Status and future of herring and sprat stocks in the Baltic Sea. Dana 10: 29-59

Patarnello T, Volckaert FAMJ, Castilho R (2007) Pillars of Hercules: Is the Atlantic-Mediterranean transition a phylogeographical break? Mol Ecol 16:4426-4444

Raymond M, Rousset F (1995) GENEPOP (version 1.2): population genetics software for exact tests and ecumenicism. J Hered 86:248-249

Rice WR (1989) Analyzing tables of statistical tests. Evolution 43:223-225

> Ruzzante DE, Taggart CT, Cook D (1998) A nuclear DNA basis for shelf- and bank-scale population structure in northwest Atlantic cod (Gadus morhua): Labrador to Georges Bank. Mol Ecol 7:1663-1680

Schneider S, Kueffer JM, Roessli D, Excoffier L (2000) ARLEQUIN version 2000: a software for population genetics data analysis. Genetics and Biometry Laboratory, University of Geneva

Stepputtis D (2006) Distribution patterns of Baltic sprat (Sprattus sprattus L.) - causes and consequences. PhD dissertation, Christian Albrechts University, Kiel

> Tomkiewicz J, Lehmann KM, St John MA (1998) Oceanographic influences on the distribution of Baltic cod, Gadus morhua, during spawning in the Bornholm Basin of the Baltic Sea. Fish Oceanogr 7:48-62 
Väinölä R (2003) Repeated trans-Arctic invasions in littoral bivalves: molecular zoogeography of the Macoma balthica complex. Mar Biol 143:935-946

Van Oosterhout C, Hutchinson WF, Wills DPM, Shipley P (2004) MICRO-CHECKER: software for identifying and correcting genotyping errors in microsatellite data. Mol Ecol Notes 4:535-538

Voipio A (1981) The Baltic Sea, Vol 30. Elsevier, Amsterdam

Waples RS, Gaggiotti O (2006) What is a population? An empirical evaluation of some genetic methods for identify- ing the number of gene pools and their degree of connectivity. Mol Ecol 15:1419-1439

Weir BS, Cockerham CC (1984) Estimating F-statistics for the analysis of population structure. Evolution 38: 1358-1370

Whitehead PJP (1985) FAO species catalogue, Vol 7, Part 1. Clupeoid fishes of the world. An annotated and illustrated catalogue of the herrings, sardines, pilchards, sprats, shads, anchovies and wolf-herrings. FAO Fish Synop 125, Rome

Appendix 1. Sprattus sprattus. Summary of genetic data for the 11 samples and 9 microsatellite loci analysed. $A$ and $A_{\mathrm{r}}$ are number of alleles and allelic richness (adjusted to $\mathrm{n}=56$ ), respectively. $H_{\mathrm{E}}$ and $H_{\mathrm{O}}$ are expected and observed heterozygosity, respectively. Results of tests for deviation from Hardy-Weinberg (HW) proportions are shown by p-values, and significant deviations $(\alpha=0.05)$ after adjustment by the sequential Bonferroni method (Rice 1989) are indicated by asterisks $\left({ }^{*}\right) . F_{\mathrm{IS}}$ is the estimated inbreeding coefficient (multi-locus estimate given in parentheses). See Table 1 for sample locations

\begin{tabular}{|c|c|c|c|c|c|c|c|c|c|}
\hline Samples & Spsp47D & Spsp77C & Spsp133 & Spsp154 & Spsp170 & Spsp202 & Spsp219 & Spsp256 & Spsp275 \\
\hline \multicolumn{10}{|c|}{ GOT $(n=88)$} \\
\hline$\%$ scored & 96.6 & 98.9 & 98.9 & 92.0 & 100 & 100 & 95.5 & 98.9 & 98.9 \\
\hline$A$ & 15 & 19 & 10 & 12 & 13 & 10 & 34 & 12 & 15 \\
\hline$A_{\mathrm{r}}$ & 14.7 & 17.4 & 9.4 & 11.6 & 10.6 & 8.7 & 30.9 & 11.2 & 13.8 \\
\hline$H_{\mathrm{E}}$ & 0.820 & 0.883 & 0.724 & 0.851 & 0.754 & 0.669 & 0.945 & 0.831 & 0.893 \\
\hline$H_{\mathrm{O}}$ & 0.800 & 0.793 & 0.644 & 0.753 & 0.739 & 0.761 & 0.952 & 0.874 & 0.874 \\
\hline HW & 0.4592 & 0.0681 & 0.2218 & 0.0052 & 0.2086 & 0.2731 & 0.5806 & 0.019 & 0.6214 \\
\hline$F_{\mathrm{IS}}(0.025)$ & 0.025 & 0.103 & 0.111 & 0.115 & 0.020 & -0.139 & -0.008 & -0.051 & 0.022 \\
\hline \multicolumn{10}{|c|}{ GDA $(n=86)$} \\
\hline$\%$ scored & 95.3 & 98.8 & 97.7 & 82.6 & 95.3 & 98.8 & 90.7 & 97.7 & 98.8 \\
\hline$A$ & 17 & 18 & 10 & 11 & 13 & 10 & 29 & 11 & 17 \\
\hline$A_{\mathrm{r}}$ & 16.0 & 17.2 & 9.5 & 11.0 & 11.3 & 8.9 & 27.1 & 10.1 & 15.7 \\
\hline$H_{\mathrm{E}}$ & 0.784 & 0.860 & 0.739 & 0.833 & 0.794 & 0.708 & 0.922 & 0.836 & 0.888 \\
\hline$H_{\mathrm{O}}$ & 0.634 & 0.847 & 0.643 & 0.732 & 0.817 & 0.776 & 0.897 & 0.833 & 0.812 \\
\hline $\mathrm{HW}$ & 0.0024 & 0.1381 & 0.0041 & $0.0001^{*}$ & 0.7845 & 0.3735 & 0.2299 & 0.3863 & 0.2974 \\
\hline$F_{\mathrm{IS}}(0.051)$ & 0.192 & 0.016 & 0.131 & 0.121 & -0.029 & -0.097 & 0.027 & 0.003 & 0.086 \\
\hline \multicolumn{10}{|c|}{ BOR05 $(\mathrm{n}=82)$} \\
\hline$\%$ scored & 92.7 & 85.4 & 96.3 & 82.9 & 95.1 & 100 & 89.0 & 100 & 96.3 \\
\hline$A$ & 16 & 17 & 10 & 13 & 13 & 11 & 30 & 11 & 18 \\
\hline$A_{\mathrm{r}}$ & 15.2 & 16.4 & 9.3 & 12.4 & 11.0 & 9.6 & 27.9 & 10.2 & 17.0 \\
\hline$H_{\mathrm{E}}$ & 0.744 & 0.851 & 0.752 & 0.816 & 0.756 & 0.667 & 0.939 & 0.816 & 0.884 \\
\hline$H_{\mathrm{O}}$ & 0.724 & 0.786 & 0.671 & 0.647 & 0.756 & 0.720 & 0.932 & 0.780 & 0.810 \\
\hline HW & 0.1834 & 0.0014 & 0.0690 & 0.0009 & 0.1686 & 0.2133 & 0.3060 & 0.7501 & 0.1391 \\
\hline$F_{\mathrm{IS}}(0.056)$ & 0.028 & 0.077 & 0.109 & 0.208 & 0.000 & -0.079 & 0.008 & 0.043 & 0.084 \\
\hline \multicolumn{10}{|c|}{ BOR06 $(\mathrm{n}=88)$} \\
\hline$\%$ scored & 98.9 & 96.6 & 100 & 92.0 & 100 & 100 & 95.5 & 97.7 & 97.7 \\
\hline$A$ & 17 & 20 & 7 & 12 & 14 & 10 & 28 & 13 & 15 \\
\hline$A_{\mathrm{r}}$ & 16.0 & 19.0 & 6.6 & 11.3 & 11.5 & 8.9 & 25.2 & 12.1 & 13.6 \\
\hline$H_{\mathrm{E}}$ & 0.809 & 0.911 & 0.713 & 0.848 & 0.801 & 0.692 & 0.927 & 0.863 & 0.877 \\
\hline$H_{\mathrm{O}}$ & 0.678 & 0.788 & 0.568 & 0.741 & 0.818 & 0.682 & 0.952 & 0.872 & 0.860 \\
\hline HW & 0.0059 & 0.0076 & $0.0004^{*}$ & 0.0034 & 0.5786 & 0.2434 & 0.6609 & 0.0936 & 0.6224 \\
\hline$F_{\mathrm{IS}}(0.065)$ & 0.162 & 0.135 & 0.204 & 0.127 & -0.022 & 0.014 & -0.028 & -0.010 & 0.019 \\
\hline
\end{tabular}


Appendix 1 (continued)

\begin{tabular}{|c|c|c|c|c|c|c|c|c|c|}
\hline Samples & Spsp47D & Spsp77C & Spsp133 & Spsp154 & Spsp170 & Spsp202 & Spsp219 & Spsp256 & Spsp275 \\
\hline \multicolumn{10}{|c|}{$\operatorname{ARK}(n=78)$} \\
\hline$\%$ scored & 98.7 & 97.4 & 94.9 & 76.9 & 94.9 & 97.4 & 84.6 & 96.2 & 89.7 \\
\hline$A$ & 16 & 19 & 10 & 13 & 15 & 7 & 27 & 13 & 14 \\
\hline$A_{\mathrm{r}}$ & 15.4 & 17.5 & 9.3 & 12.9 & 13.4 & 6.8 & 25.7 & 12.1 & 13.6 \\
\hline$H_{\mathrm{E}}$ & 0.806 & 0.871 & 0.681 & 0.869 & 0.796 & 0.616 & 0.931 & 0.841 & 0.875 \\
\hline$H_{\mathrm{O}}$ & 0.792 & 0.803 & 0.649 & 0.717 & 0.757 & 0.645 & 0.909 & 0.920 & 0.829 \\
\hline HW & 0.0881 & 0.2480 & 0.2621 & 0.0337 & 0.6923 & 0.7540 & 0.4396 & 0.0162 & 0.1073 \\
\hline$F_{\text {IS }}(0.037)$ & 0.018 & 0.079 & 0.048 & 0.177 & 0.050 & -0.047 & 0.024 & -0.094 & 0.053 \\
\hline \multicolumn{10}{|c|}{$\operatorname{BEL}(n=83)$} \\
\hline$\%$ scored & 88.0 & 89.2 & 92.8 & 90.4 & 88.0 & 94.0 & 88.0 & 98.8 & 96.4 \\
\hline$A$ & 13 & 22 & 12 & 11 & 21 & 10 & 30 & 15 & 20 \\
\hline$A_{\mathrm{r}}$ & 13.0 & 20.8 & 11.3 & 10.9 & 19.8 & 9.0 & 28.3 & 14.2 & 18.5 \\
\hline$H_{\mathrm{E}}$ & 0.843 & 0.919 & 0.755 & 0.790 & 0.901 & 0.652 & 0.955 & 0.860 & 0.841 \\
\hline$H_{\mathrm{O}}$ & 0.699 & 0.877 & 0.584 & 0.699 & 0.767 & 0.680 & 0.986 & 0.805 & 0.825 \\
\hline HW & 0.0102 & 0.0013 & $0.0005^{*}$ & 0.0287 & 0.0218 & 0.5818 & 0.6733 & 0.6285 & 0.0161 \\
\hline$F_{\text {IS }}(0.079)$ & 0.171 & 0.046 & 0.226 & 0.116 & 0.148 & -0.042 & -0.032 & 0.065 & 0.020 \\
\hline \multicolumn{10}{|c|}{$\operatorname{KAT}(\mathrm{n}=81)$} \\
\hline$\%$ scored & 90.1 & 92.6 & 95.1 & 69.1 & 87.7 & 96.3 & 91.4 & 97.5 & 96.3 \\
\hline$A$ & 19 & 22 & 10 & 11 & 22 & 14 & 28 & 13 & 22 \\
\hline$A_{\mathrm{r}}$ & 17.7 & 20.1 & 9.1 & 11.0 & 20.9 & 12.1 & 26.1 & 12.3 & 20.7 \\
\hline$H_{\mathrm{E}}$ & 0.849 & 0.903 & 0.717 & 0.817 & 0.906 & 0.717 & 0.935 & 0.834 & 0.898 \\
\hline$H_{\mathrm{O}}$ & 0.822 & 0.840 & 0.636 & 0.804 & 0.662 & 0.808 & 0.946 & 0.797 & 0.846 \\
\hline HW & 0.1578 & 0.1158 & 0.1962 & 0.1403 & $0.0000^{*}$ & 0.0290 & 0.0180 & 0.6864 & 0.0877 \\
\hline$F_{\text {IS }}(0.055)$ & 0.032 & 0.070 & 0.113 & 0.016 & 0.271 & -0.128 & -0.012 & 0.045 & 0.058 \\
\hline \multicolumn{10}{|c|}{ GER04 $(n=88)$} \\
\hline$\%$ scored & 100 & 89.8 & 98.9 & 97.7 & 100 & 98.9 & 100 & 100 & 100 \\
\hline$A$ & 18 & 24 & 12 & 12 & 28 & 11 & 37 & 15 & 25 \\
\hline$A_{\mathrm{r}}$ & 16.7 & 21.9 & 11.0 & 11.7 & 26.2 & 10.1 & 32.5 & 13.4 & 22.7 \\
\hline$H_{\mathrm{E}}$ & 0.879 & 0.923 & 0.778 & 0.782 & 0.952 & 0.790 & 0.957 & 0.848 & 0.907 \\
\hline$H_{\mathrm{O}}$ & 0.852 & 0.785 & 0.644 & 0.674 & 0.898 & 0.759 & 0.920 & 0.807 & 0.875 \\
\hline HW & 0.4506 & $0.0005^{*}$ & 0.0199 & $0.0003^{*}$ & 0.1982 & 0.1296 & 0.1254 & 0.046 & 0.6384 \\
\hline$F_{\text {IS }}(0.077)$ & 0.031 & 0.150 & 0.173 & 0.138 & 0.057 & 0.040 & 0.039 & 0.049 & 0.035 \\
\hline \multicolumn{10}{|c|}{$\operatorname{GER05}(n=87)$} \\
\hline$\%$ scored & 95.4 & 96.6 & 97.7 & 97.7 & 86.2 & 97.7 & 98.9 & 100 & 97.7 \\
\hline$A$ & 19 & 19 & 13 & 11 & 28 & 12 & 35 & 17 & 23 \\
\hline$A_{\mathrm{r}}$ & 17.4 & 18.5 & 11.2 & 10.4 & 26.2 & 10.9 & 30.9 & 15.4 & 21.7 \\
\hline$H_{\mathrm{E}}$ & 0.823 & 0.927 & 0.717 & 0.725 & 0.945 & 0.780 & 0.953 & 0.854 & 0.921 \\
\hline$H_{\mathrm{O}}$ & 0.807 & 0.857 & 0.565 & 0.718 & 0.907 & 0.718 & 0.942 & 0.816 & 0.859 \\
\hline HW & 0.0613 & 0.3379 & 0.0011 & 0.0886 & 0.3200 & 0.0873 & 0.0680 & 0.1800 & 0.0166 \\
\hline$F_{\text {IS }}(0.060)$ & 0.020 & 0.076 & 0.213 & 0.010 & 0.040 & 0.080 & 0.012 & 0.045 & 0.068 \\
\hline \multicolumn{10}{|c|}{$\operatorname{CEL}(n=85)$} \\
\hline$\%$ scored & 92.9 & 89.4 & 96.5 & 83.5 & 90.6 & 92.9 & 91.8 & 94.1 & 95.3 \\
\hline$A$ & 19 & 19 & 10 & 9 & 26 & 11 & 30 & 17 & 22 \\
\hline$A_{\mathrm{r}}$ & 17.2 & 18.0 & 8.6 & 8.8 & 23.1 & 10.6 & 26.9 & 15.6 & 20.3 \\
\hline$H_{\mathrm{E}}$ & 0.836 & 0.902 & 0.636 & 0.736 & 0.915 & 0.740 & 0.942 & 0.826 & 0.902 \\
\hline$H_{\mathrm{O}}$ & 0.785 & 0.842 & 0.634 & 0.690 & 0.688 & 0.772 & 0.859 & 0.825 & 0.877 \\
\hline HW & 0.0179 & 0.0104 & 0.3654 & 0.0331 & $0.0000^{*}$ & 0.0038 & 0.0105 & 0.3446 & 0.6927 \\
\hline$F_{\text {IS }}(0.062)$ & 0.062 & 0.066 & 0.002 & 0.063 & 0.249 & -0.044 & 0.088 & 0.001 & 0.028 \\
\hline \multicolumn{10}{|c|}{$\operatorname{ADR}(n=85)$} \\
\hline$\%$ scored & 98.8 & 98.8 & 100 & 84.7 & 100 & 97.6 & 100 & 100 & 100 \\
\hline$A$ & 14 & 26 & 10 & 11 & 22 & 20 & 33 & 15 & 10 \\
\hline$A_{\mathrm{r}}$ & 13.0 & 24.1 & 9.2 & 10.6 & 19.4 & 18.1 & 28.7 & 14.1 & 8.7 \\
\hline$H_{\mathrm{E}}$ & 0.724 & 0.942 & 0.724 & 0.844 & 0.749 & 0.882 & 0.943 & 0.803 & 0.455 \\
\hline$H_{\mathrm{O}}$ & 0.690 & 0.929 & 0.506 & 0.833 & 0.706 & 0.735 & 0.894 & 0.729 & 0.388 \\
\hline HW & 0.0021 & 0.1177 & $0.0002^{*}$ & 0.4476 & 0.0734 & 0.0019 & 0.3465 & 0.4068 & 0.0070 \\
\hline$F_{\text {IS }}(0.093)$ & 0.047 & 0.015 & 0.303 & 0.013 & 0.058 & 0.168 & 0.052 & 0.092 & 0.147 \\
\hline
\end{tabular}

